\title{
Vinorelbine Tartrate Emulsion
}

National Cancer Institute

\section{Source}

National Cancer Institute. Vinorelbine Tartrate Emulsion. NCI Thesaurus. Code C66943.

An emulsion containing the tartrate salt of the semisynthetic vinca alkaloid vinorelbine with antineoplastic activity. Vinorelbine binds to tubulin, inhibiting tubulin polymerization into microtubules; cell division is prevented, the cell cycle is arrested metaphase and cell death ensues. In this formulation vinorelbine is emulsified in a homogeneous suspension of nanoparticles, which protects the venous endothelium from coming into direct contact with the active ing redient, potentially reducing vinorelbine-associated venous toxicity at the venous injection site. 